Journal of

Language and

JLD (PRINT) ISSN 2397-2637

Discrimination

JLD (ONLINE) ISSN 2397-2645

Review

\title{
Gender, Power and Political Speech: Women and Language in the 2015 UK General Election \\ By D. Cameron and S. Shaw (2016) London: Palgrave Macmillan, 152pp.
}

Reviewed by Melissa Yoong

KEYWORDS: LANGUAGE IDEOLOGY; WOMEN IN POLITICS; GENDERED SPEECH STYLES; CO-OPERATION AND COMPETITION; MEDIA DISCOURSE

Gender, Power and Political Speech explores the notion of women's 'different voice' in politics, a voice that is often believed to emphasise co-operation over competition and aggression. As Cameron and Shaw explain in the first chapter, this book aims to uncover if male and female party leaders used language differently in key public speech events of the 2015 UK General Election (henceforth, GE2015) and to what extent media representations of the women's performances were shaped by ideological preconceptions about their 'different voice.' To this end, the case study examines two televised debates held during the election campaign from the dual perspective of linguistic production and reception. It first analyses inter- and intragender differences in the verbal behaviour of the participants, and then compares the findings with media representations of the female politicians and their speech. The investigation on reception in this book largely focuses on the media's assessment of the debate performances, rather than the opinion of the electorate. This restriction in scope is not a weakness of the case study, but a natural consequence of conducting an in-depth and nuanced analysis of complex data in a book of this length. While an audience reception study would have been an interesting follow-up analysis, examining press reporting is an important contribution of this work, given the media's role in shaping 'the contours of public discourse on gender and

\section{Affiliation}

University of Nottingham Malaysia, Malaysia email: melissa.yoong@nottingham.edu.my 
political leadership' (p. 80), especially as the national debates generated extensive commentary in the British newspapers.

This book contains four chapters. Chapter 1 traces the development of the 'different voice' ideology through influential academic texts and popular culture books, before exploring linguistic and political science research on male dominance in political discourse and the complex factors influencing verbal behaviour in institutional settings. While gender and language scholars will likely find themselves in familiar territory, those new to this field of research will find much food for thought in this critical review of pertinent studies. Cameron and Shaw then discuss the wider as well as immediate political context surrounding the speech events central to the election campaign and this book, namely the ITV 'Leaders' debate' and the $\mathrm{BBC}$ 'Challengers' debate'. As the book appears to be written for a wide audience, the background information provided here will certainly be useful for readers who are unfamiliar with UK politics. The chapter closes with a general account of the case study approach and the methodology employed.

Chapter 2 interrogates the linguistic behaviour of the party leaders in the national debates. Analysing these debates as opposed to other public speech events of GE2015 is a key contribution of this book as it enables the examination of women's interactional styles in a fundamentally adversarial genre, that is of the type often presumed to pose problems for female politicians. Given that the leaders were subjected to the same conditions and rules in the debates, their verbal strategies can also be directly compared while controlling for factors such as speech genre. Cameron and Shaw draw on principles and insights from Conversation Analysis and interactional sociolinguistics to examine the ways in which the politicians gained, held and yielded the debate floor as well as the linguistic strategies that they used to position themselves and their opponents. It may not surprise the reader that the findings do not support the 'different voice' stereotype. All participants utilised both adversarial and supportive discourse strategies, though the range and balance varied by individual. Cameron and Shaw convincingly argue that the leaders' performances were more directly related to the relative status of their parties and their political and public speaking experience than to gender.

Of particular note is how co-operative and 'relational' strategies, which were not used consistently in the televised debates during the 2010 UK election campaign (Drake and Higgins 2012), appear to have now become conventionalised. The authors attribute this development to the complex demands of the speech genre that encourage integrating "traditionally "masculine" norms of adversarial debate with "feminine" communication

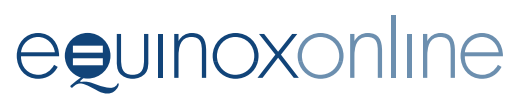


styles which help to construct "authenticity" and build rapport with the viewer at home' (p. 74). This could potentially raise questions for some readers about the effects of combining these styles on the reception of the politicians' performances. Previous research on gender, language and leadership in business settings, for example, found that men are valued for using relational forms of discourse, and tolerated or even admired when adopting assertive behaviour. Women, in contrast, risk being evaluated negatively for using equivalent communicative strategies (Baxter 2008). These questions are partly addressed in the book. The analysis of election press coverage in Chapter 3 indicates that, like women in positions of authority in other professional contexts, female party leaders are caught in a 'double bind'. In this case,

the coexistence of conflicting ideologies of gender and political speech (one proposing that women are and should be different from men, the other proposing that their effectiveness as politicians depends on being able to 'land punches' in competition with men) ... sets up contradictory expectations which women can fail to meet if they are perceived as either too far from the male norm ... or too close to it, given that they are not actually male. (p. 99)

The data presented in the book seem to suggest a trend towards negative media representations of the men's performances in the debate, specifically of their normatively 'masculine' behaviour. However, there is insufficient evidence to establish if the male leaders' use of supportive speech benefited them or passed unnoticed despite the influence of the 'different voice' ideology. In this respect, the media assessments of the men's communication styles could have been more fully explored in this study.

Chapter 3 examines media representations of the three women party leaders through a critical discourse analysis of a sample of election coverage in national or English editions of newspapers. This complements existing studies on equitable media reporting of female and male politicians by asking 'not just how much is being said about women, but also what is being said, and what kind of language is being used to say it' (p. 82). The qualitative analysis clearly shows that the media reception of the female party leaders' political speech was significantly shaped by the notion of women's 'different voice.' The press commentary on the female leaders' speech styles in the televised debates did not accurately reflect the women's actual linguistic behaviour, which was more strongly gendered in reception than in production. Some of the most interesting findings in this chapter are not directly related to the central question of the 'different voice' ideology, but paint a more complex picture of common complaints about the media's sexist treatment of women in politics. For example, Cameron and Shaw

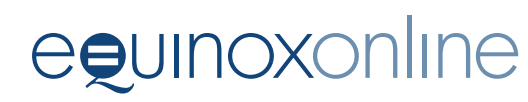


make the crucial observation that the differences in the balance between positive, negative and 'neutral' coverage of the three female leaders reflect 'the newspapers' general ideological sympathies, political calculations about what kind of threat they represented to the party the newspaper did support, and perceptions of a leader's performance in the campaign' ( $p$. $86)$. In other words, the sexism in the election coverage was 'more a means to an end than an end in itself' (p. 89). The findings also challenge the belief that only women politicians receive trivialising coverage. The issue, as the authors point out, is that the male and female leaders are differently positioned by such commentary, which in turn reinforces the problematic association of political power and authority with maleness.

The fourth and final chapter recaps the study's key findings and considers their practical and scholarly implications. As televised debates become a significant part of election campaigns, researchers in language, gender, media and politics may be interested in Cameron and Shaw's discussion on the reduced relevance of concepts that have been useful for examining gendered behaviour in institutional settings, such as 'insiders' and 'interlopers', in the context of mediated political discourse.

Overall, Gender, Power and Political Speech is a very insightful case study that will appeal to scholars and students working in the areas of discourse analysis, gender, politics and media studies. The highly engaging analyses were strongly argued, and the close attention to detail makes this book invaluable reading material for discourse analysis as well as language and gender courses.

\section{References}

Baxter, J. (2008) Is it tough talking at the top? A post-structuralist analysis of the construction of gendered speaker identities of British business leaders within interview narratives. Gender and Language 2(2): 197-222. https://doi.org/10.1558/genl. v2i2.197

Drake, P. and Higgins, M. (2012) Lights, camera, election: celebrity, performance and the 2010 UK General Election leadership debates. British Journal of Politics E International Relations 14(3): 375-91. https://doi.org/10.1111/j.1467-856X.2011.00504.x 